УДК 347.965 .42

DOI https://doi.org/10.32849/2663-5313/2020.6.02

\title{
Наталія Бондарчук,
}

канд. юрид. наук, дочент,

доцент кафедри правознавства

Поліського національного університету

\section{Наталія Мошківська,}

студентка ОС «Магістр» спеиіальності «Право»

Поліського національного університету

\section{СУЧАСНІ ТЕНДЕНЦІЇ ВПРОВАДЖЕННЯ МЕДІАЦІЇ В УКРАЇНІ}

У статті проведено аналіз використання медіачії в різних життєвих сферах, розглянуто натрями ї розвитку в Украйні, а також наведені спростування поширених заперечень щодо застосування медіачії.

Від початку свого життя людина бореться за своє місие в ньому, кожна особистість має свою індивідуальність, свої інтереси та бачить світ по-своєму. Кожна людина дивиться на одну й ту саму річ по-іншому, тому суперечності неминучі, як і конфлікти та спори. С безліч варіантів вирішення суперечностей, відстоювання свого права, однак лише медіація дає можливість дійти консенсусу. Сьогодні медіачія виступає не тільки як ефективний спосіб подолання вищезгаданих життєвих явищ, але iє гарною альтернативою вирішенню спорів (конфліктів) у суді. Першопрохідием у використанні медіачіі для вирішення конфліктів стали Сполучені Штати Америки, де у 1976 рочі відбулась Паундська конферениія, яка сприяла популяризаиії медіації. Саме після иієї події почалося активне впровадження інститутів альтернативного вирішення спорів у країнах Свропи. Стаття розкриває зміст ефективності медіації для застосування майже у всіх сферах життя. При ивому слід зауважити, що вона не дає гарантії вирішення конфлікту, але лише медіація, як один із альтернативних методів вирішення суперечок (спорів, конфліктів), надає можливість вирішити спір (конфлікт) шляхом досягнення консенсусу між сторонами, про що свідчить ї̈ активне застосування та впровадження Інститутів медіаиії у країнах Європи. Україна вже дано стоїть на межі впровадження медіації, хоча суперечності щодо ефективності процесу медіації не зникають. Навіть без законодавчого регулювання медіація в Україні набуває стрімкого розвитку, однак гостро постає питання про ӥ впровадження на законодавчому рівні. Саме визнання на законодавчому рівні сприятиме зростанню довіри до медіації як до альтернативного та ефективного методу вирішення конфліктів (спорів). Слід також наголосити на потребі популяризації медіації в Україні, що може сприяти впевненості суспільства у ї̈ ефективності.

Ключові слова: посередництво, медіація, бізнес медіації, альтернативне врегулювання спору, об'єднання медіаторів, сфери застосування медіації, заперечення застосування медіації, примирення, досягнення консенсусу.

Постановка проблеми. Актуальність теми зумовлена впровадженням інституту медіації в Україні, необхідністю його розвитку та популяризації, тобто поширення інформації щодо можливості альтернативного вирішення спорів у різних сферах виникнення конфліктів (спорів).

Стан дослідження. Процедура вирішення спорів шляхом медіації не є новиною для України, однак до сьогодні це питання було законодавчо не врегульоване, та, навіть не зважаючи на це, вирішення спорів за допомогою процесу медіації в Україні стрімко зростає.

Дослідженням медіації як альтернативного способу врегулювання спорів займалися багато науковців, серед яких можна виділити й українських представників юридичних наук, таких як: В. Землянська, Н. Гайдук, Д. Проценко, Л. Герасіна, Т. Подковенко, В. Жмудь, О. Кармаза та інші.

У законодавстві України вже закладені основи позасудового вирішення спорів, можливість укладення «мирової угоди» передбачена в Цивільному процесуальному та Господарському процесуальному кодексах України, Кримінальному та Кримінальнопроцесуальному кодексах України, також передбачена процедура примирення сторін у певних категоріях справ.

Ще у 2006 році в Україні відбулося визнання на державному рівні необхідності такої процедури, як медіація, про що йдеться в Указі Президента України «Про Концепцію удосконалення судівництва для утвердження справедливого суду в Україні відповідно 
до європейських стандартів». Одним із завдань цієї концепції виступає «створення можливостей для розвитку альтернативних, тобто позасудових, способів розв'язання спорів $[1$, c. 1$]$.

У серпні 2019 року Міністром юстиції України в Сінгапурі було підписано Конвенцію Організації Об'єднаних Націй щодо медіації [2, с. 1]. Також в Україні було декілька спроб затвердження процедури медіації на законодавчому рівні, однак кожного разу законопроекти не проходили затвердження.

Метою статті є розгляд тенденцій розвитку та аналіз ринку послуг 3 надання медіації в Україні, а також спростування поширених заперечень щодо застосування медіації для вирішення різного роду спорів та конфліктів.

Виклад основного матеріалу. Навіть попри відсутність визначеності на законодавчому рівні, сьогодні медіація як альтернативний спосіб вирішення спорів в Україні набуває стрімкого розвитку, про що свідчить зростаюча кількість навчальних центрів та об'єднань безпосередньо медіаторів.

Натепер відомо, що 22 квітня 2020 року Уряд схвалив проєкт Закону України «Про медіацію», передбачивши доопрацювати його у триденний термін з урахуванням декількох зауважень. Проєктом даного закону визначається порядок та правові засади проведення медіації [3, с. 1]. Однак важливим фактором $€$ те, що затвердження медіації на законодавчому рівні дасть можливість визначити права й обов'язки медіатора та сторін процесу медіації, а також врегулює питання щодо вимог до договору про медіацію та угоди про врегулювання спору за результатами медіації.

Як зазначає Т. Подковенко, розвиток медіації в сучасному світі зумовлюється такими реальними викликами, з якими стикаються, хоча й не завжди можуть впоратися судові системи. Саме до таких проблем слід віднести:

- довгу тривалість судових процесів; справ;

- великі витрати на ведення судових

- надмірна заформалізованість процедури;

- певні складнощі у правовому регулюванні.

Саме тому на сучасному етапі розвитку українського суспільства медіація з повним правом може розглядатись як один із перспективних та ефективних способів альтернативного вирішення конфліктів [4, с. 26-29].

Медіація - це переговори за участю третьої незалежної сторони, яка зацікавлена в тому, щоб сторони вирішили свій спір мак- симально вигідно для обох. Третя незалежна сторона - це медіатор, він не вносить своїх пропозицій щодо вирішення спору, а є лише посередником, допомагає прийти до спільного вирішення конфлікту. Т. Подковенко також відзначає, що медіатор не є суддею чи арбітром - він не судить і не виносить жодних рішень. Роль медіатора полягає в тому, щоб, завдяки знанням певних медіаційних технологій, допомогти знайти порозуміння і задовольнити інтереси сторін [5, c. 4].

Ціль медіації - це спонукання сторін спору в досягненні консенсусу, який надалі письмово фіксується. Також варто зазначити, що медіація - це краща альтернатива судовому процесу, яка зберігає можливість звернення до суду у будь-який час, за бажанням однієї зі сторін. Вона не гарантує вирішення проблеми, але дає шанс на вирішення iï поза судом, з дотриманням основних принципів:

- рівноправності сторін;

- нейтральності та неупередженості медіатора;

- конфіденційності;

- добровільності участі в процесі медіації.

Основні концепції розвитку інституту медіації розглядає О. Кармаза та зазначає, що процес медіації, врегульований на законодавчому рівні, буде сприяти швидкому вирішенню цивільних, господарських, сімейних, трудових та адміністративних спорів без залучення коштів із державного чи місцевих бюджетів, а також зменшить навантаження судів, а домовленості, досягнуті в процесі медіації, будуть дотримуватись [6, с. 1].

Про стрімкий розвиток медіації в Україні свідчить процес створення низки організацій та об'єднань, що займаються вирішенням спорів та різного роду конфліктів за допомогою процедури медіації. Щодо розвитку ринку послуг медіації, то С. Скрипник визначає розвиток медіації в Україні у двох напрямах: практичному та теоретичному [7, с. 1]

Перший - теоретичний, що передбачає навчання медіатора та характеризується функціонуванням ряду асоціацій, шкіл та тренерів, які займаються викладанням техніки та навчають основним принципам проведення медіації. Існує декілька варіантів програм для навчання медіаторів, залежно від сфери, в якій будуть надаватись послуги медіації, однак всі вони базуються на опануванні основного курсу, здобутті базових навичок медіатора.

Навчання та тренінги 3 медіації проводять навіть під час пандемії та довготривалого карантину в Україні, відбувається активне проведення он-лайн лекцій та семінарів. Також у даний період постає питання 
про проведення процедури медіації он-лайн, однак такий варіант вирішення спорів має певні недоліки, оскільки існує можливість недотримання головних принципів медіації. Для такого формату вирішення спору конфлікт має бути вчасно виявлений, а сторони мають бути якнайбільше впевненими в добросовісності та порядності одна одної.

Сьогодні можна виділити декілька варіантів об'єднання медіаторів:

1) за географічним розташуванням (об'єднуються медіатори, що мають зручне розташування для ведення спільної діяльності);

2) за спеціалізацією (сімейні медіатори, бізнес медіатори, медіатори на ринку креативних ідей (тобто в IT та IB сферах)).

Другий напрям - практичний, про що свідчить активне її використання для вирішення сімейних спорів та побутових конфліктів у цивільних спорах.

Слід розглянути сучасний стан та тенденції розвитку ринку медіації, доцільність використання альтернативних вирішень спорів. Тренер 3 медіації Європейського рівня, що професійно займається посередництвом у вирішенні конфліктів з 2010 року, С. Петрова, голова правління Центру права і посередництва, під час проведення відкритих лекцій та на своїй сторінці Інстаграм проводить аналіз трендів у застосуванні медіації.

Отже, сьогодні можна виділити такі сфери, в яких можливе застосування медіації. Сфера сімейної медіації, яка $є$ найбільш актуальною. Звісно, не варто стверджувати, що всі сімейні спори є медіабельними, однак здебільшого застосування альтернативного способу вирішення спору може сприяти збереженню взаємин у майбутньому. Під час виникнення сімейних конфліктів сторони переважно не чують одна одну, медіатор виступає в даному випадку посередником у вирішенні конфлікту, він допомагає сторонам почути одна одну.

Сьогодні існує варіант ко-медіації, тобто залучення до процесу вирішення спору двох медіаторів, у вирішенні сімейних спорів; це, мабуть, кращий варіант, оскільки знижується можливість упущення факторів сприяння вирішенню даного виду спору. Однак головним фактором застосування медіації у сімейній сфері виступає добровільність проведення медіації. Адже існує безліч таємниць сімейного життя, висвітлення та обговорення яких можна уникнути, враховуючи принцип конфіденційності, оскільки без згоди відповідної сторони медіатор не вправі надавати інформацію іншій стороні. Отже, під час вирішення сімейних спорів за допомогою медіації можливо не тільки дійти до спільного консенсусу, але й відновити відносини між сторонами та навіть зберегти шлюб.

Сфера бізнес медіації. Перевагою у вирішенні бізнес конфліктів є принцип конфіденційності та економії часу, оскільки для бізнесу, за словами відомого американського політика Б. Франкліна, «час - це гроші» і важливою умовою виступає його використання з користю та можливість збереження партнерських відносин. Конфіденційне вирішення спорів у бізнесі не тільки допоможе уникнути розголосу справи, а більшою мірою забезпечить збереження авторитету компанії, а отже, відносин з іншими партнерами або навіть сприятиме залученню їх до співпраці.

Кваліфікований бізнес-медіатор, на відміну від звернення до суду, сприяє полегшенню вирішення спору, вивчаючи варіанти з різних кутів зору та обговорюючи варіанти конструктивного врегулювання. Світова тенденція демонструє, що компанії різних розмірів застосовують медіаційні підходи до вирішення спорів, що сприяє уникненню затяжного судового розгляду та використання над-витратного арбітражу [8, с. 1].

У своїй статті Т. Сидоришина зазначає, що сучасні компанії, «акули бізнесу», задля вирішення своїх конфліктів (спорів) все частіше вибирають інститут медіації, який передбачає залучення посередника (медіатора) для вирішення спору [9, с. 1].

Бізнес медіація може бути в таких варіантах:

- медіація між бізнес-партнерами, оскільки, попри партнерські відносини, конфлікти можуть з'являтися на різних етапах співпраці (на початку бізнесу, під час спільної діяльності та особливо на етапі завершення співпраці);

- медіація у комерційній діяльності, яка передбачає, що під час встановлення договірних відносин до договору включається окремий пункт, який регулює вирішення спорів за допомогою процедури медіації.

Сфера фінансової медіації - вирішення конфліктів у фінансовому секторі, де існує велика кількість проблемної та кредитної заборгованості. Зокрема, кращим варіантом буде, коли банк і боржник шукатимуть вихід із ситуації, яка склалася, разом за допомогою процедури медіації.

Медіація в IT та IB сферах, тобто на ринку креативних ідей. Для вирішення спорів, що пов'язані із захистом прав інтелектуальної власності, також можна використовувати медіацію, яка дає змогу зекономити час порівняно з розглядом відповідних спорів у суді, а також можливість проведення он-лайн медіації. 
Ініціаторами медіації в публічній сфері $\epsilon$ державні органи або органи місцевого самоврядування. Як зазначає С. Петрова, застосування так званої «community mediation» - проведення процедури медіації всередині об'єднань - сьогодні тільки розпочинається [10, с. 1].

Наостанок слід зазначити, що внаслідок останніх подій (пандемія та довготривалі карантинні заходи) криза неминуча, однак ніхто не відміняє виконання договірних, кредитних та орендних зобов'язань, навіть запровадження відстрочок не звільнить від виконання попередніх зобов'язань. Такі питання можна вирішувати в суді, однак потрібно буде доводити причинно-наслідкові зв'язки між форс-мажорними обставинами та неможливістю виконання своїх обов'язків, а результат не завжди буде позитивним для обох сторін. Саме у таких випадках раціональним буде застосування медіації у бізнесі.

Також варто зазначити, що для того, щоб уникнути опору під час популяризації медіації як одного з ефективних методів вирішення спорів, варто спростувати такі поширені заперечення:

1. Медіація може бути прийнята як ознака слабкості, оскільки доведеться зійти зі своєї позиції. Насправді медіація дає можливість не зосереджуватись на предметі спору, а взяти до уваги сукупність усіх обставин та майбутнє, що дозволить визначити спільні інтереси.

2. Це нічого не дасть, тому що сторони вже давно не спілкуються та ненавидять одна одну. Цей часто вживаний аргумент є результатом нерозуміння суті медіації. Насправді, медіація дозволяє сторонам показати свої почуття, емоції, що може допомогти їм відновити діалог з метою спільного пошуку спільних інтересів.

3. Сторони вже вели безрезультатні переговори, звернення до медіатора нічого не змінить. Скоріш за все, сторони обговорювали кожен свою позицію, внаслідок цього і не дійшли порозуміння, саме на цьому етапі час вдатися до медіації, до переговорів за участю третьої сторони, яка допоможе у пошуку консенсусу.

4. Острах надто рано або надто пізно звернутися до процедури медіації. Слід вкотре зазначити, що медіація може бути ефективною як на початку зародження конфлікту, так і тоді, коли конфлікт затягнувся на тривалий час.

5. Інша сторона поводить себе недобросовісно, оскільки має зовсім іншу позицію. Саме медіація дозволяє сторонам зрозуміти одна одну і те, що інша сторона має свою позицію, зовсім не означає, що вона поводить себе недобросовісно.

\section{Висновки}

Отже, спираючись на викладений вище матеріал та враховуючи теоретичний та практичний досвід країн Свропи, можна зазначити, що медіація може застосовуватись для вирішення різного виду конфліктів (спорів). Як зазначає Т. Подковенко, медіація є перспективною та здатна конкурувати з іншими процедурами вирішення спорів, оскільки у кожної з цих процедур своя відповідна ніша у вирішенні юридичних спорів [4, с. 29].

Справді, у правовому розвитку України медіація є перспективною, однак слід наголосити, що дана процедура потребує здійснення її популяризації з метою збільшення довіри суспільства. Потрібно інформувати суспільство про можливість не тільки вирішення конфлікту в цілому, а й досягнення консенсусу у спірних питаннях саме за допомогою проведення процедури медіації.

\section{Список використаних джерел:}

1. Про концепцію вдосконалення судівництва для утвердження справедливого суду в Україні відповідно до європейських стандартів : Указ Президента України № 361/2006 від 10 травня 2006 p. URL: http://www.zakon.rada.gov.ua/laws/ show/361/2006 (дата звернення: 01.05.2020).

2. УКРІНФОРМ. Мультимедійна платформа іномовлення в Україні. URL: https://www. ukrinform.ua/rubric-economy/2755938-ukrainapidpisala-konvenciu-oon-pro-vreguluvanna-sporivza-rezultatami-mediacii.html (дата звернення: 01.05.2020).

3. УКРІНФОРМ. Мультимедійна платформа іномовлення в Україні. URL:https://www. ukrinform.ua/rubric-society/3010705-kabminshvalivzakonoproekt-pro-mediaciu-z-urahuvannamzauvazen.html (дата звернення: 01.05.2020).

4. ПодковенкоТ. Інститут медіації: зарубіжний досвід та українські перспективи. Акту альні проблеми правознавства: зб. наук. праць. 2016. Вип. 1. С. 26-31. URL: http://www.nbuv. gov.ua/UJRN/aprpr_2016_1_7 (дата звернення: 01.05.2020).

5. Подковенко.Т.О. Медіація як один з альтернативних способів розв'язання конфліктів. Держава і право. Юридичні і політичні науки : збір. наукових праць. 2009. Випуск 45. С. 32. URL: http://dspace.nbuv.gov.ua/bitstream/Podkovenko. pdf (дата звернення: 01.05.2020).

6. Кармаза О. Інститут медіації: основні концепції розвитку. Підприємництво, господарство і право. 2017. № 2. C. 24-28. URL: http://nbuv. gov.ua/UJRN/Pgip_2017_2_6 (дата звернення: 01.05.2020).

7. Сисоєнко М. Тема: Техніка медіації. Українсвкий юрист. 2019. № 9. URL: https://www.jurist. ua/article/1856 (дата звернення: 01.05.2020).

8. Що таке бізнес медіація і навішо вона потрібна / Український центр медіації. URL: 
http://ukrmediation.com.ua/ru/poleznayainformatsiya/v-svobodnom-dostupe/2083-shchotake-biznes-mediatsiya-i-navishcho-vona-potribna (дата звернення: 01.05.2020).

9. Сидоришина Т. Медіація - нова фішка комунікації. Юридична газета. 2019 № 38-39 (692-693). URL: http://www.yur-gazeta. com/ publications/practice/inshe/mediaciyanova-fishka-komunikaciyi.html (дата звернення: 01.05.2020).

10. Петрова С. Какие тренды в медиации 2020? / Instagram. Дата оновлення 26.12.2019. URL: $\quad$ http://www.instagram.com/petrova mediator? igshid=169ella819tsj (дата звернення: 01.05.2020).

11. Жмудь В. Запровадження процедури медіації (примирення) у законодавстві України. URL: https://minjust.gov.ua/m/str_11347 (дата звернення: 01.05.2020).

12. Землянська В. Альтернатива судам - належить вам. Юридична газета. 2007. № 17. URL : http://bihun.in.ua/uploads/tx_upspubs/I_2007 Zemlyanska.pdf (дата звернення: 01.05 .2020 ).

13. Альтернативні підходи до розв'язання конфліктів: теорія і практика застосування / уклад.: Н. Гайдук, І. Сенюта, О. Бік, Х. Терешко. Львів : ПАІС, 2007. 296 c.

14. Директива № 2008/52/ЄС Європейського парламенту і Ради про деякі аспекти посередництва (медіації) в цивільних та комерційних справах (документ 994_а95, поточна редакція від 21.05.2008). URL : http://www.zakon.rada.gov. ua/laws/show/994_a95lang=uk (дата звернення: 01.05.2020).

Nataliia Bondarchuk, Nataliia Moshkivska. Current trends of the implementation of mediation in Ukraine

The article analyzes the use of mediation in various spheres of life, considers the directions of its development in Ukraine, as well as refutes the common objections to the use of mediation.

From the beginning of his life a person fights for his place in it, each person has his own individuality, his own interests and sees the world in his own way. Everyone looks at the same thing differently, so contradictions are inevitable, as are conflicts and disputes. There are many options for resolving disputes, defending their rights, but only mediation allows to reach a consensus. Today, mediation is not only an effective way to resolve the above-mentioned life events, but it is also a good alternative to resolving disputes (conflicts) in court. The pioneer in the use of mediation to resolve conflicts was the United States of America, wherein 1976 a Pound Conference was held to promote mediation. It was after this event that the active introduction of alternative dispute resolution institutions in European countries began. The article reveals the content of the effectiveness of mediation for use in almost all spheres of life. However, it should be noted that it does not guarantee the settlement of the conflict, but only mediation, as one of the alternative methods of resolving disputes (disputes, conflicts) provides an opportunity to resolve the dispute (conflict) by consensus between the parties, as evidenced by its active use and introduction of Mediation Institutes in European countries. Ukraine is already on the verge of introducing mediation, although controversy over the effectiveness of the mediation process has not disappeared. Even without legislative regulation, mediation in Ukraine is rapidly developing, but the question of its implementation at the legislative level is acute. Recognition at the legislative level will contribute to the growth of trust in mediation as an alternative and effective method of resolving conflicts (disputes). It should also be emphasized the significant need to promote mediation in Ukraine, which can serve to raise public confidence in its effectiveness.

Key words: mediation, mediation, business mediation, alternative dispute resolution, association of mediators, areas of mediation, denial of mediation, reconciliation, consensus building. 